Louisiana State University

LSU Digital Commons

Faculty Publications

Department of Chemistry

$1-1-2011$

\title{
Efficient synthesis and reactions of 1,2-dipyrrolylethynes
}

\author{
Hillary K. Tanui \\ Louisiana State University \\ Erhong $\mathrm{HaO}$ \\ Anhui Normal University \\ Moses I. Ihachi \\ Louisiana State University \\ Frank R. Fronczek \\ Louisiana State University \\ Kevin M. Smith \\ Louisiana State University
}

See next page for additional authors

Follow this and additional works at: https://digitalcommons.Isu.edu/chemistry_pubs

\section{Recommended Citation}

Tanui, H., Hao, E., Ihachi, M., Fronczek, F., Smith, K., \& Vicente, M. (2011). Efficient synthesis and reactions of 1,2-dipyrrolylethynes. Journal of Porphyrins and Phthalocyanines, 15 (5-6), 412-420. https://doi.org/ 10.1142/S1088424611003331

This Article is brought to you for free and open access by the Department of Chemistry at LSU Digital Commons. It has been accepted for inclusion in Faculty Publications by an authorized administrator of LSU Digital Commons. For more information, please contact ir@lsu.edu. 
Authors

Hillary K. Tanui, Erhong Hao, Moses I. Ihachi, Frank R. Fronczek, Kevin M. Smith, and M. Graça H. Vicente 


\title{
Efficient synthesis and reactions of 1,2-dipyrrolylethynes
}

\author{
Hillary K. Tanui ${ }^{\mathrm{a}}$, Erhong Hao ${ }^{\mathrm{b}}$, Moses I. Ihachi ${ }^{\mathrm{a}}$, Frank R. Fronczek ${ }^{\mathrm{a}}$, Kevin M. Smith ${ }^{\mathrm{a}, \diamond}$, \\ and M. Graça H. Vicente ${ }^{a,{ }^{*}, \diamond}$ \\ aDepartment of Chemistry, Louisiana State University, Baton Rouge, LA 70803, USA \\ ${ }^{b}$ Anhui Key Laboratory of Functional Molecular Solids and Anhui Key Laboratory of Molecular \\ Based Materials, College of Chemistry and Material Science, Anhui Normal University, Wuhu, \\ Anhui 241000, China
}

\begin{abstract}
Various dipyrroles possess important motifs for construction of pyrrole-containing pigments. A series of 1,2-dipyrrolylethynes (4a-d) has been efficiently synthesized using an improved one-pot double Sonagashira coupling from trimethylsilylethyne and various 2-iodopyrroles. The resulting 1,2-dipyrrolylethynes were further transformed into novel indolyl-, ethenyl- and carboranyldipyrroles (5-7) using the Larock indole synthesis, stereoselective catalytic hydrogenation, or $\mathrm{B}_{10} \mathrm{H}_{14}$. Indolyl-dipyrroles were found to selectively bind fluoride ions using one pyrrolic and the indolyl NHs, whereas the carboranyl- and ethenyl-dipyrroles are potentially valuable precursors for the synthesis of porphyrin isomers and expanded pigments.
\end{abstract}

\section{Keywords}

carborane; dipyrrole; indole; Larock; Sonagashira

\section{INTRODUCTION}

\begin{abstract}
In recent years, the chemistry of pyrrole-containing pigments has received increasing attention in coordination chemistry, medicinal chemistry, and material science [1]. Various kinds of dipyrroles have been synthesized and some have been used as building blocks in the construction of various functional molecules [2]. Among these, dipyrrolylethynes such as $\mathbf{A}$ in Fig. 1, can be found only sparsely in the literature (five examples according to a SciFinder search). Compound $\mathbf{A}$ was first synthesized by Vogel and coworkers as a key intermediate during their synthesis of $22 \pi$-electron expanded (or "stretched") porphycene-(2.2.2.2) via $\mathbf{B}$ (Fig. 1) [3, 4]. Later, Lightner and coworkers adapted this methodology for the sysnthesis of alkynyl-homobilirubins [5]. The method for synthesis of dipyrrolylethynes involves a threestep 60\% overall yield sequence (coupling-desilylation-coupling), using trimethylsilylethyne as the source of the alkyne bridge. At least two column separations are required for purification before the target compound is isolated.
\end{abstract}

We are interested in new approaches to compound $\mathbf{A}$ due to its synthetic utility as a conjugated pyrrole-containing precursor for cycloadditive macrocyclization. Furthermore, the rich chemistry of the alkyne functionality provides the opportunity to synthesize other

Copyright $\odot 2011$ World Scientific Publishing Company

*Correspondence to: M. Graça H. Vicente, vicente@1su.edu, tel: +1 225-578-7442.

'SPP full member in good standing

Dedicated to Professor John A. Shelnutt on the occasion of his $65^{\text {th }}$ birthday 
novel dipyrrole motifs. Inspired by Grieco's recently developed one-pot synthesis of biarylalkynes [6], we have developed and now report a one-pot synthesis of dipyrrolylethynes. Our ethynyl products were then further transformed into various related dipyrroles (5-7) using the Larock indole synthesis, stereoselective catalytic hydrogenation, or reaction with decaborane. In particular, the new indolyldipyrroles were found to have high fluorescence quantum yields and to selectively bind fluoride ions in a 2:1 (host: $\mathrm{F}^{-}$) complex. Pyrrole and indole-based fluoride probes have been incorporated within conjugated systems for colorimetric and/or fluorescence detection of fluoride ions, because of their strong hydrogen bonding $\left[\mathrm{F}^{-} \ldots . \mathrm{H}-\mathrm{N}\right]$ interactions, as well as their high stability over a wide range of $\mathrm{pH}$ values [7-9]. On the other hand, the carboranyl- and ethenyl-dipyrroles are valuable precursors for the synthesis of porphyrin isomers and other polypyrrolic materials $[10,11]$.

\section{RESULTS AND DISCUSSION}

Our overall synthesis of dipyrrole (4a) from readily available 2-iodopyrrole (1a) [12] is shown in Scheme 1. First, a three-step sequence (coupling-desilylation-coupling) using trimethylsilylethyne as the source of the 2-atom alkynyl bridge was used, as previously described [13]. Classical Sonagashira coupling between 1a and trimethylsilylethyne gave pyrrole 2 in $89 \%$ yield. Desilylation using tetrabutylammonium fluoride (TBAF) provided the terminal ethynylpyrrole (3) in 95\% yield. The final coupling between compounds $1 \mathbf{a}$ and 3 afforded dipyrrolylethyne (4a) in $73 \%$ yield. Alternatively, a 1-step procedure for the formation of 4a using a double Sonagashira coupling reaction between 2-iodopyrrole 1a and trimethylsilyllethyne was investigated. Although Vogel [3] and later Kim [4] both reported very low yields for the direct formation of the dipyrrolylethyne using iodopyrrole and ethyne, using Grieco's method [6] we were able to develop a one-pot reaction between 2iodopyrrole 1a and trimethylsilylethyne (Scheme 1) which gave $4 \mathrm{a}$ in $62 \%$ yield. In this synthetic approach, the coupling reaction was performed using trimethylsilylethyne instead of ethyne, with DBU as the base. The reaction was followed using TLC since the target dipyrrolylethyne displays characteristic bright blue fluorescence under ultraviolet (366 nm) light. The workup of the reaction was very simple and required no chromatographic purification; after extraction with ethyl acetate it only required methanol washing to obtain analytically pure product. The 1-step methodology proved to be reproducible and routinely gave 55-65\% yields of the target dipyrrolylethyne products, on a $10 \mathrm{mmol}$ scale. Use of another solvent, such as acetonitrile in place of benzene, also gave similar results. The onepot reaction was extended to the synthesis of dipyrrolylethynes (4b) and (4c) in 52 and 54\% yields, respectively (Table 1). However, when $N$-tosyl-2-bromopyrrole (1d) was used, a poor yield of dipyrrolylethyne $\mathbf{4 d}$ was obtained (8\%) using these conditions.

We were able to grow suitable crystals for X-ray analysis of all dipyrrolylethynes $\mathbf{4 a - d}$, by slow evaporation of dichloromethane solutions. The X-ray structures of $\mathbf{4 a}$ and $\mathbf{4 c}$ are shown in Figs 2 and 3, respectively. In compound 4a, the two pyrrole rings are twisted about the triple-bond line with a dihedral angle of $33.26(3)^{\circ}$, and the $\mathrm{C}-\mathrm{C}$ triple bond distance is $1.205(2) \AA$. The molecule lies on a twofold axis in the crystal. In compound $\mathbf{4 c}$, the molecule does not lie on a symmetry element in the crystal, and the pyrroles are twisted considerably more than in $\mathbf{4 a}$, forming a dihedral angle of $69.25(6)^{\circ}$. The triple-bond distance is 1.203(3) $\AA$. The difference in conformation between $\mathbf{4 a}$ and $\mathbf{4 c}$ appears to be related to hydrogen bonding. In both, each pyrrole and adjacent ester $\mathrm{C}=\mathrm{O}$ form an intermolecular cyclic hydrogen bond dimer. However, in $\mathbf{4 a}$, these 10-membered rings lie on inversion centers, thus the pyrroles are strictly parallel. In $\mathbf{4 c}$, they deviate sharply from parallelism, forming a dihedral angle of $64.59(6)^{\circ}$. We have previously reported the molecular structures of $\mathbf{4 b}$ and $\mathbf{4 d}$ [14]. 
Novel indolyldipyrroles $\mathbf{5 a}$ and $\mathbf{5 c}$ were prepared in 55-60\% yields via the Larock indole synthesis [15] from the corresponding dipyrrolylethynes 4a,c, as shown in Scheme 2. On the other hand, with several dipyrrolylethynes available we explored the Lindlar reduction of the alkyne bond to generate novel 1,2-dipyrrolylethene derivatives. Using Lindlar's catalyst [16] in the absence of quinoline, dipyrrolylethene (6) was synthesized from $\mathbf{4 c}$ in $31 \%$ yield.

Stereoselective semi-hydrogenation employing HSiEt3 as the reductant [17] also yielded the cis-dipyrrolylalkene $\mathbf{6}$. This transformation opens up the possibility for synthesis of porphycenes by way of Ullmann type self-coupling of derivatives of $\mathbf{6}$, and also of expanded $22 \pi$-electron stretched porphycenes.

The X-ray structure of $\mathbf{5 c}$ is shown in Fig. 4. One pyrrole at the $\alpha$-position of the indole moiety is rotated to present its $\mathrm{NH}$ group approximately coplanar with that of the indole, forming an $\mathrm{N}-\mathrm{C}-\mathrm{C}-\mathrm{N}$ torsion angle of $30.7(3)^{\circ}$. Thus, both of these two $\mathrm{NH}$ groups are able to donate their hydrogen bonds to the same acceptor, forming two convergent intermolecular hydrogen bonds to an ester carbonyl $\mathrm{O}$ atom.

The photophysical properties of indolyl-dipyrroles $\mathbf{5 a}$ and $\mathbf{5} \mathbf{c}$ were investigated, compared with those of the dipyrrolylethyne precursors, and the results obtained are summarized in Table 2. Interestingly, dipyrroles $\mathbf{5 a}$ and $\mathbf{5 c}$ show strong absorption bands centered around $300 \mathrm{~nm}$ (blue shifted from those of the corresponding dipyrrolylethynes 4), and strong fluorescence emission bands at $\sim 440 \mathrm{~nm}$ with surprisingly high quantum yields ( 0.91 for $\mathbf{5 a}$ and 0.88 for 5c) [18]. Fluorescence titration experiments using dipyrroles 5 and TBAF, revealed dramatic fluorescence quenching upon addition of TBAF, as seen in Fig. 5.

Addition of other anions, such as bromide, chloride, and hydrogenosulfate did not cause such pronounced fluorescence quenching, probably due to their lower affinity for binding to the pyrrole and indole NH and their larger size. The Job's plot shown in Fig. 6a indicates that compound 2a chelates with TABF in a 2:1 stoichiometry, with an association constant $(K)$ of $8.32 \times 10^{4} \mathrm{M}^{-1}$ based on the Hill plot shown in Fig. 6b. Although compound $\mathbf{5 c}$ also chelated with bromide and hydrogeno-sulfate in a 2:1 molar ratio with binding constants $5.89 \times 10^{4} \mathrm{M}^{-1}$ and $7.94 \times 10^{3} \mathrm{M}^{-1}$, respectively, the Hill coefficients are greater than one, suggesting that these two systems are positively cooperative. The crystal structure obtained of dipyrrole $\mathbf{5} \mathbf{c}$ in the presence of 10 equivalents excess of fluoride shows the formation of a dimer complex consisting of two molecules of $\mathbf{5 c}$ coordinating one fluoride ion that occupies the center of the molecule, as shown in Fig. 7. Dipyrrole 5c forms a 2:1 crystalline complex with TBAF in which the fluoride ion is chelated by four hydrogen-bonded pyrrole $\mathrm{N}-\mathrm{H}$ groups. Two of the N-F distances are quite short, 2.566(4) and 2.574(4) $\AA$, and those hydrogen bonds are fairly linear, with N-H-F angles 168 and $169^{\circ}$. The other two are longer, 2.855(4), 2.938(4) $\AA$ and less linear, in bifurcated hydrogen bonds with ester carbonyl acceptors. The TBA cation perches on top of this hydrogen-bonded aggregate, with N-F distance 3.894(5) $\AA$.

Inspired by electropolymerization results previously reported [10] for carboranyl-containing pyrroles and thiophenes, in particular for the ortho-carboranyl systems which produced the most conjugated and conductive polymers, we turned our attention to the synthesis of orthocarboranyldipyrrole 7, as shown in Scheme 3. The ortho-carborane cluster was obtained in $29 \%$ yield by reaction of dipyrrolylethyne $\mathbf{4 a}$ with decaborane and diethylsulfide in toluene [18]. Interestingly carboranyl-dipyrrole 7 showed the highest fluorescence quantum yield (0.98) of all dipyrroles synthesized.

The X-ray structure of $\mathbf{7}$ is shown in Fig. 8. In the solid state, the two pyrroles are cofacial, presenting their $\mathrm{NH}$ groups on the same side of the carborane cage. The pyrrole rings are not parallel, forming a dihedral angle of $63.05(5)^{\circ}$. As in $\mathbf{4 a}$ and $\mathbf{4 c}$, the pyrroles and their adjacent ester carbonyls form intermolecular hydrogen bonds within 10-membered rings. In 
this case, two molecules of $\mathbf{7}$ form a hydrogen-bonded dimer via four hydrogen bonds in two 10-membered rings, as shown in Fig. 8 (right panel). Carboranyl-dipyrrole $\mathbf{7}$ is a very valuable starting material to built carborane-containing macro-cycles and polymers.

\section{EXPERIMENTAL}

\section{General}

Reagents were purchased as reagent-grade and used without further purification unless otherwise stated. Solvents were used as received from commercial suppliers unless noted otherwise. THF was freshly distilled from sodium benzophenone ketyl. All reactions were performed using oven-dried or flame-dried glassware unless otherwise stated, and were monitored by TLC using $0.25 \mathrm{~mm}$ silica gel plates with UV indicator (60F-254). Carborane was detected by immersion into $\mathrm{PdCl}_{2}$ in aqueous $\mathrm{HCl}$ solution $\left(1 \mathrm{~g} \mathrm{PdCl}_{2}\right.$ in $80 \mathrm{~mL}$ water and $20 \mathrm{~mL}$ conc. $\mathrm{HCl}$ ) and heated to develop a black spot on TLC. ${ }^{1} \mathrm{H}$ and ${ }^{13} \mathrm{C}$ NMR were obtained on a $250 \mathrm{MHz}$ or $300 \mathrm{MHz}$ spectrometer at room temperature. Chemical shifts $(\delta)$ are given in ppm relative to $\mathrm{CDCl}_{3} 7.26\left({ }^{1} \mathrm{H}\right)$ and $77 \mathrm{ppm}\left({ }^{13} \mathrm{C}\right)$ or to internal TMS. Highresolution mass spectra were obtained by using quadrupole time-of-flight mass spectrometry with a nano LC system. MALDI-TOF mass spectra were obtained on an Applied Biosystems QSTAR XL instrument, using positive mode with dithranol as matrix unless otherwise indicated. Compounds 1a-c were prepared according to the literature [12]. UVvisible absorption spectra and fluorescence emission spectra were recorded on commercial spectrophotometers. The slit width was $2.5 \mathrm{~nm}$ for excitation and $5.0 \mathrm{~nm}$ for emission. Relative quantum efficiencies of fluorescence of dipyrroles were obtained by comparing the areas under the corrected emission spectrum of the test sample with that of quinine sulfate as the standard ( 0.56 in $0.1 \mathrm{M} \mathrm{H}_{2} \mathrm{SO}_{4}$ aqueous solutions). Non-degassed, spectroscopic grade solvents and a $10 \mathrm{~mm}$ quartz cuvette were used. Dilute solutions $(0.01<\mathrm{A}<0.05)$ were used to minimize reabsorption effects. Quantum yields were determined using the following equation [19]:

$$
\Phi_{\mathrm{x}}=\Phi_{\mathrm{S}}\left(\mathrm{I}_{\mathrm{x}} / \mathrm{I}_{\mathrm{S}}\right)\left(\mathrm{A}_{\mathrm{s}} / \mathrm{A}_{\mathrm{x}}\right)\left(\eta_{\mathrm{x}} / \eta_{\mathrm{s}}\right)^{2}
$$

where $\Phi_{S}$ is the reported quantum yield of the standard, I is the integrated emission spectra, $A$ is the absorbance at the excitation wavelength and $\eta$ is the refractive index of the solvent being used $(\eta=1$ when the same solvent was used for both the test sample and the standard). An X subscript refers to the test sample, and an S subscript is for the standard.

\section{Synthesis}

Benzyl 5-ethynyl-4-ethyl-3-methylpyrrole-2-carboxy- late (3)-To a solution of benzyl 4-ethyl-5-iodo-3-methylpyrrole- 2-carboxylate (1a) $(3.69 \mathrm{~g}, 10 \mathrm{mmol})$ in diethylamine $(100 \mathrm{~mL})$ were added under argon (trimethylsilyl)acetylene $(1.5 \mathrm{~g}, 15 \mathrm{mmol})$, dichlorobis(triphenylphosphine)palladium(II) (125 mg, $0.175 \mathrm{mmol})$, and copper(I) iodide ( $65 \mathrm{mg}, 0.35 \mathrm{mmol})$. The homogeneous mixture was stirred at $50{ }^{\circ} \mathrm{C}$ for $2 \mathrm{~h}$ until TLC showed that no starting material remained. After evaporation of the solvent under vacuum, the residue was subjected to chromatography on a short silica gel column with hexane/ dichloromethane/ethyl acetate (5:1:1) as eluent, to give $\mathbf{2}$ (3.02 $\mathrm{g}, 89 \%)$. To a solution of 2 $(2.71 \mathrm{~g}, 8.0 \mathrm{mmol})$ in THF $(50 \mathrm{~mL})$ was added $\mathrm{Bu}_{4} \mathrm{NF}(1.0 \mathrm{M}$ THF solution, $8 \mathrm{~mL})$. After being stirred for $1 \mathrm{~h}$, the resulting mixture was concentrated under reduced pressure. The crude residue was subjected to chromatography on a short silica gel column with dichloromethane as eluent to give $\mathbf{3}$ as a white solid (2.03 g, 95\% yield). ${ }^{1} \mathrm{H} \mathrm{NMR}\left(\mathrm{CDCl}_{3}\right.$, $250 \mathrm{MHz}): \delta$, ppm $9.19(1 \mathrm{H}, \mathrm{s}), 7.31-7.36(5 \mathrm{H}, \mathrm{m}), 5.28(2 \mathrm{H}, \mathrm{s}), 3.29(1 \mathrm{H}, \mathrm{s}), 2.47-2.50$ $(2 \mathrm{H}, \mathrm{m}), 2.25(3 \mathrm{H}, \mathrm{s}), 1.00-1.11(3 \mathrm{H}, \mathrm{m}) .{ }^{13} \mathrm{C} \mathrm{NMR}\left(\mathrm{CDCl}_{3}, 75 \mathrm{MHz}\right): \delta, \mathrm{ppm} 161.2,136.6$, 
$133.7,129.0,128.9,128.6,126.5,119.8,114.1,82.6,75.5,66.4,18.4,15.3,10.8 . \mathrm{MS}(\mathrm{EI})$ : $\mathrm{m} / z 267.15[\mathrm{M}]^{+}$.

1,2-bis[2-(5-benzyloxycarbonyl-4-ethyl-3-methyl-pyrrolyl)]ethyne (4a)-Method $A$ : To a solution of benzyl 4-ethyl-5-iodo-3-methylpyrrole-2-carboxylate (1a) (1.85 g, 5 mmol) and benzyl 5-ethynyl-4-ethyl-3-methylpyrrole-2 -carboxylate (3) (1.34 g, $5 \mathrm{mmol})$ in diethylamine $(50 \mathrm{~mL})$ were added dichlorobis(triphenylphosphine)palladium(II) (59 mg, $0.08 \mathrm{mmol}$ ) and copper(I) iodide (30 mg, $0.16 \mathrm{mmol})$. The homogeneous mixture was stirred at $50{ }^{\circ} \mathrm{C}$ for $3 \mathrm{~h}$. After evaporation of the solvent in vacuo, the residue was subjected to chromatography on a short silica gel column with hexane/dichloromethane/ethyl acetate $(5: 1: 1)$ as eluent to give $4 \mathbf{a}(1.75 \mathrm{~g}, 73 \%)$. Method B: A $250 \mathrm{~mL}$ Schlenk tube with a tefloncoated magnetic stir bar was charged with $\mathrm{PdCl}_{2}\left(\mathrm{PPh}_{3}\right)_{2}(210 \mathrm{mg}, 6 \mathrm{~mol} \%)$, CuI (188 mg, $10 \mathrm{~mol} \%$ ) and benzyl 4-ethyl-5-iodo-3-methylpyrrole-2-carboxylate (1a) (3.69 g, $10 \mathrm{mmol})$. The system was pumped with a vacuum pump and refilled with nitrogen gas three times. Then dry benzene $40 \mathrm{~mL}$, sparged with dry argon was added by syringe. Argon-sparged DBU (9.0 mL, 6 equiv.) in $5 \mathrm{~mL}$ dry benzene was then added via syringe and ice-chilled trimethylsilylethyne $(0.71 \mathrm{~mL}, 0.50$ equiv. $)$ in $5 \mathrm{~mL}$ dry benzene was added by syringe, followed immediately by distilled water $(73 \mu \mathrm{L}, 40 \mathrm{~mol} \%)$. The reaction flask was covered with aluminum foil and left stirring at a high rate of speed for $2 \mathrm{~d}$ until no starting material was left according to TLC; the reaction mixture was partitioned between ethyl acetate and brine $(200 \mathrm{~mL}$ each). The organic layer was washed with $10 \% \mathrm{HCl}(3 \times 200 \mathrm{~mL})$, saturated aqueous $\mathrm{NaCl}(200 \mathrm{~mL})$, dried over anhydrous $\mathrm{NaSO}_{4}$, gravity-filtered and the solvent then removed in vacuo. The crude product was washed with methanol and dried under vacuum, giving $1.57 \mathrm{~g}\left(62 \%\right.$ yield) of the title compound. ${ }^{1} \mathrm{H} \mathrm{NMR}\left(\mathrm{CDCl}_{3}, 250 \mathrm{MHz}\right): \delta, \mathrm{ppm} 8.86$ $(2 \mathrm{H}, \mathrm{s}), 7.38-7.41(10 \mathrm{H}, \mathrm{m}), 5.31(4 \mathrm{H}, \mathrm{s}), 2.53-2.56(4 \mathrm{H}, \mathrm{m}), 2.30(6 \mathrm{H}, \mathrm{s}), 1.11-1.14(6 \mathrm{H}$, m). ${ }^{13} \mathrm{C} \mathrm{NMR}\left(\mathrm{CDCl}_{3}, 75 \mathrm{MHz}\right): \delta$, ppm 162.2, 137.7, 134.6, 133.6, 130.2, 129.8, 127.9, 121.2, 115.8, 86.6, 67.6, 19.8, 16.5, 11.9. HRMS (ESI-TOF): $m / z$ 509.2444 [M + H] $]^{+}$, calcd. for $\mathrm{C}_{32} \mathrm{H}_{33} \mathrm{~N}_{2} \mathrm{O}_{4} 509.2435$.

1,2-bis[2-(5-benzyloxycarbonyl-3,4-dimethylpyrrolyl)]ethyne (4b)-This compound was obtained in 54\% yield using the above method B and recrystallized from dichloromethane to afford colorless crystals. ${ }^{1} \mathrm{H} \mathrm{NMR}\left(250 \mathrm{MHz}, \mathrm{CDCl}_{3}\right)$ : $\delta$, ppm 11.99 $(2 \mathrm{H}, \mathrm{s}), 7.47-7.32(10 \mathrm{H}, \mathrm{m}), 5.29(4 \mathrm{H}, \mathrm{s}), 2.2(6 \mathrm{H}, \mathrm{s}), 2.0(6 \mathrm{H}, \mathrm{s}) . \mathrm{MS}(\mathrm{EI}): \mathrm{m} / \mathrm{z} 480.129$ $[\mathrm{M}]^{+}$.

1,2-bis[2-(5-ethoxycarbonyl-3,4-dimethylpyrrolyl)]ethyne (4c)-This compound was obtained in $52 \%$ yield using the above method $\mathrm{B}$ and recrystallized from dichloromethane to afford colorless crystals. ${ }^{1} \mathrm{H} \mathrm{NMR}\left(250 \mathrm{MHz}, \mathrm{CDCl}_{3}\right): \delta, \mathrm{ppm} 8.80(2 \mathrm{H}$, s), 4.34 (4H. q, $J=7.01 \mathrm{~Hz}), 2.35(6 \mathrm{H}, \mathrm{s}), 2.10(6 \mathrm{H}, \mathrm{s}), 1.37(6 \mathrm{H}, \mathrm{t}, J=7.05 \mathrm{~Hz}) .{ }^{13} \mathrm{C} \mathrm{NMR}$ $\left(63 \mathrm{MHz} \mathrm{CDCl}_{3}\right)$ : $\delta$, ppm 10.3, 10.9, 14.9, 60.6, 86.0, 114.8, 120.3, 126.9, 160.6. HRMS (MALDI-TOF): $m / z, 357.1807[\mathrm{M}+\mathrm{H}]^{+}$, calcd. for $\mathrm{C}_{20} \mathrm{H}_{25} \mathrm{~N}_{2} \mathrm{O}_{4} 357.1808$.

1,2-bis( $\boldsymbol{N}$-tosylpyrrolyl)ethyne (4d)-To a $50 \mathrm{~mL}$ round bottom flask was added 2bromo-1-tosyl-pyrrole $(0.3 \mathrm{~g}, 1 \mathrm{mmol})$ followed by $\mathrm{Pd}(\mathrm{PPh})_{2} \mathrm{Cl}_{2}(0.042 \mathrm{~g}, 0.06 \mathrm{mmol})$ and $\mathrm{CuI}(0.038 \mathrm{~g}, 0.2 \mathrm{mmol})$. The flask was sealed and placed in a dry ice bath under $\mathrm{N}_{2}$. Trimethylsilylethyne $(0.072 \mathrm{~mL}, 0.5 \mathrm{mmol}), \mathrm{DBU}(0.9 \mathrm{~mL}, 6 \mathrm{mmol})$ and water $(0.0072 \mathrm{~mL}$, 40 molar equiv.) were dissolved in benzene $(5 \mathrm{~mL})$ and added to the reaction flask. After freezing the mixture in a dry ice bath, the flask was evacuated and nitrogen gas was added. The resulting reaction mixture was allowed to warm slowly to room temperature and was stirred until complete disappearance of the starting material, as monitored by TLC. The mixture was worked up by adding ethyl acetate $(100 \mathrm{~mL})$, and washing the organic layer three times with brine. The organic phase was dried over anhydrous $\mathrm{Na}_{2} \mathrm{CO}_{3}$ and 
concentrated under reduced pressure. The crude mixture was purified by flash column chromatography using hexane/ethyl acetate (5:1) for elution. The bispyrrolylethyne (4d) was obtained in $8.4 \%$ yield $(0.02 \mathrm{~g})$ and recrystallized from dichloromethane to afford colorless crystals. mp $185-186{ }^{\circ} \mathrm{C} .{ }^{1} \mathrm{H}$ NMR $\left(250 \mathrm{MHz}, \mathrm{CDCl}_{3}\right.$ ): $\delta$, ppm $7.9(4 \mathrm{H}, \mathrm{br}), 7.4(4 \mathrm{H}, \mathrm{br})$, $7.3(2 \mathrm{H}, \mathrm{br}, 2 \mathrm{H}), 6.71(2 \mathrm{H}, \mathrm{br}), 6.34(2 \mathrm{H}, \mathrm{br}), 2.42(6 \mathrm{H}, \mathrm{s})$. HRMS (MALDI-TOF): $\mathrm{m} / \mathrm{z}$ $465.0939[\mathrm{M}+\mathrm{H}]^{+}$, calcd. for $\mathrm{C}_{24} \mathrm{H}_{21} \mathrm{O}_{4} \mathrm{~N}_{2} \mathrm{~S}_{2} 465.0943$.

2,3-bis[2-(5-ethoxycarbonyl-3-ethyl-4-methylpyrrolyl)]-indole (5c)-1,2-bis[2-(5ethoxycarbonyl-3,4- dimethylpyrrolyl)]ethyne $(\mathbf{4 c})(0.36 \mathrm{~g}, 1 \mathrm{mmol})$ was added to a $100 \mathrm{~mL}$ reaction tube together with 2-iodoaniline $(0.44 \mathrm{~g}, 2 \mathrm{mmol}), \mathrm{Pd}(\mathrm{OAc})_{2}(0.02 \mathrm{~g}, 0.1 \mathrm{mmol})$, $\mathrm{LiCl}(0.04 \mathrm{~g}, 1 \mathrm{mmol})$, and $\mathrm{K}_{2} \mathrm{CO}_{3}(1.38 \mathrm{~g}, 10 \mathrm{mmol})$ and dissolved in $25 \mathrm{~mL}$ of DMF. The mixture was placed in a dry ice bath, evacuated, purged with nitrogen gas and then allowed to warm to room temperature and heated at $80^{\circ} \mathrm{C}$ for $2 \mathrm{~d}$. The reaction was monitored by TLC. Ethyl acetate $(150 \mathrm{~mL})$ was added to the reaction mixture and the organic layer was washed with brine $(3 \times 100 \mathrm{~mL})$. The organic phase was dried over anhydrous $\mathrm{NaHCO}_{3}$ and concentrated under reduced pressure. The crude mixture was purified by flash column chromatography on silica gel using hexane/ethyl acetate $(7: 1)$ as eluant. The product (5c) was obtained $(0.25 \mathrm{~g})$ in $55 \%$ yield and recrys-tallized from dichloromethane to give colorless crystals. mp $45-47{ }^{\circ} \mathrm{C} .{ }^{1} \mathrm{H}$ NMR $\left(250 \mathrm{MHz}, \mathrm{CDCl}_{3}\right): \delta$, ppm $8.86(1 \mathrm{H}, \mathrm{s}), 8.83$ $(1 \mathrm{H}, \mathrm{s}), 8.47(1 \mathrm{H}, \mathrm{s}), 7.53(1 \mathrm{H}, \mathrm{d}, J=7.45 \mathrm{~Hz}), 7.45(1 \mathrm{H}, \mathrm{d}, J=7.91 \mathrm{~Hz}), 7.24(2 \mathrm{H}, \mathrm{m}), 4.33$ $(2 \mathrm{H}, \mathrm{q}, J=7.12 \mathrm{~Hz}), 4.23(2 \mathrm{H}, \mathrm{q}, J=6.98 \mathrm{~Hz}), 2.37(3 \mathrm{H}, \mathrm{s}), 2.30(3 \mathrm{H}, \mathrm{s}), 2.11(3 \mathrm{H}, \mathrm{s}), 1.79$ $(3 \mathrm{H}, \mathrm{s}), 1.39(3 \mathrm{H}, \mathrm{t}, J=7.19 \mathrm{~Hz}), 1.32(3 \mathrm{H}, \mathrm{t}, J=6.96 \mathrm{~Hz}) .{ }^{13} \mathrm{C} \mathrm{NMR}\left(63 \mathrm{MHz}, \mathrm{CDCl}_{3}\right): \delta$, ppm 9.9, 10.4, 10.7, 11.2, 14.7, 14.9, 60.3, 60.4, 105.9, 111.4, 119.5, 119.6, 120.0, 120.2, 121.3, 123.6, 124.6, 126.6, 128.1, 128.2, 128.8, 136.1, 161.6, 161.2. HRMS (ESI-TOF): $\mathrm{m} / \mathrm{z}$ $448.2221[\mathrm{M}+\mathrm{H}]^{+}$, calcd. for $\mathrm{C}_{26} \mathrm{H}_{30} \mathrm{~N}_{3} \mathrm{O}_{4} 448.2231$.

2,3-bis[2-(5-benzyloxycarbonyl-3,4-dimethylpyrrolyl)]-indole (5a)-Prepared using above method from $\mathbf{4 a}$ in $54 \%$ yield and recrystallized from dichloromethane to give colorless crystals. mp 53-54 ${ }^{\circ} \mathrm{C} .{ }^{1} \mathrm{H}$ NMR $\left(250 \mathrm{MHz}, \mathrm{CDCl}_{3}\right): \delta$, ppm $8.82(1 \mathrm{H}, \mathrm{s}), 8.80$ $(1 \mathrm{H}, \mathrm{s}), 8.30(1 \mathrm{H}, \mathrm{s}), 7.34(14 \mathrm{H}, \mathrm{m}), 5.28(2 \mathrm{H}, \mathrm{s}), 5.18(2 \mathrm{H}, \mathrm{s}), 2.60(2 \mathrm{H}, \mathrm{q}, J=7.56 \mathrm{~Hz})$, $2.31(3 \mathrm{H}, \mathrm{s}), 2.34(3 \mathrm{H}, \mathrm{s}), 2.23(2 \mathrm{H}, \mathrm{q}, J=7.58 \mathrm{~Hz}), 1.11(3 \mathrm{H}, \mathrm{t}, J=7.53 \mathrm{~Hz}), 0.82(3 \mathrm{H}, \mathrm{t}, J$ $=7.58 \mathrm{~Hz}) .{ }^{13} \mathrm{C} \mathrm{NMR}\left(63 \mathrm{MHz}, \mathrm{CDCl}_{3}\right): \delta$, ppm 10.6, 11.2, 15.2, 15.7, 18.1, 66.0, 106.1, $111.4,119.5,119.8,123.6,126.3,127.3,128.4,128.5,128.8,128.9,129.2,136.0,136.6$, 161.7. HRMS (ESI-TOF): $\mathrm{m} / z 600.2889[\mathrm{M}+\mathrm{H}]^{+}$, calcd. for $\mathrm{C}_{38} \mathrm{H}_{38} \mathrm{~N}_{3} \mathrm{O}_{4} 600.2863$.

\section{Cis-1,2-[2-(5-ethoxycarbonyl-4-ethyl-3-methylpyrrolyl)]ethene (6)-}

Commercially available Lindlar's catalyst (5 wt.\% $\mathrm{Pd}$ on $\mathrm{CaCO}_{3}$, poisoned with lead; 150 $\mathrm{mg}, 100 \mathrm{wt} . \%)$ was added to a solution of alkyne $4 \mathbf{c}(150 \mathrm{mg}, 0.42 \mathrm{mmol})$ in dry ethyl acetate $(15 \mathrm{~mL})$. The flask was evacuated and flushed with hydrogen gas (two freeze/thaw cycles) and the mixture was stirred under hydrogen gas for $12 \mathrm{~h}$. The resulting mixture was then filtered over a Celite cake and washed with ethyl acetate $(2 \times 30 \mathrm{~mL})$. The solvent was removed under reduced pressure and the crude residue was purified by silica gel column chromatography eluting with ethyl acetate/dichloromethane/hexanes (1:1:5) to yield the title product as a yellow oil that solidified to a yellow powder $(47 \mathrm{mg}, 0.13 \mathrm{mmol}, 31 \%$ yield). ${ }^{1} \mathrm{H}$ NMR (450 MHz, $\left.\mathrm{CDCl}_{3}, 293 \mathrm{~K}\right): \delta$, ppm $8.73(2 \mathrm{H}, \mathrm{s}, \mathrm{NH}), 6.33(2 \mathrm{H}, \mathrm{s}, \mathrm{CHCH})$, $4.26\left(4 \mathrm{H}, \mathrm{q}, \mathrm{CH}_{2}\right), 2.29\left(6 \mathrm{H}, \mathrm{s}, \mathrm{CH}_{3}\right), 1.99\left(6 \mathrm{H}, \mathrm{s}, \mathrm{CH}_{3}\right), 1.30\left(6 \mathrm{H}, \mathrm{t}, \mathrm{CH}_{3}\right)$. HRMS (ESITOF): $m / z 359.1965[\mathrm{M}+\mathrm{H}]^{+}$, calcd. for $\mathrm{C}_{20} \mathrm{H}_{27} \mathrm{~N}_{2} \mathrm{O}_{4} 359.1971$.

1,2-bis[2-(5-benzyloxycarbonyl-3-ethyl-4-methylpyrrolyl)]-dodecaborane (7)A mixture of dodecaborane $(2.44 \mathrm{~g}, 3.0 \mathrm{mmol})$ and $\mathrm{Et}_{2} \mathrm{~S}(9.0 \mathrm{~mL}, 37 \mathrm{mmol})$ in $20 \mathrm{~mL}$ of dry toluene was heated at $40{ }^{\circ} \mathrm{C}$ for $2 \mathrm{~h}$ under Ar, then raised to $60^{\circ} \mathrm{C}$ for $3 \mathrm{~h}$. Then $4 \mathrm{a}(1.06 \mathrm{~g}, 2$ $\mathrm{mmol}$ ) in $20 \mathrm{~mL}$ toluene was added into the mixture via a syringe, and the mixture was 
heated to $80^{\circ} \mathrm{C}$ for $2 \mathrm{~d}$ under argon. After TLC indicated no 4a remained, the mixture was cooled to room temperature and excess decarborane was destroyed by adding methanol. The solvent was removed under reduced pressure and ethanol was added to allow codistillation of $\mathrm{Et}_{2} \mathrm{~S}$. The residue was purified on a silica gel column using $25 \%$ ethyl acetate in hexane as eluant, giving the title compound $(0.363 \mathrm{~g})$ in $29 \%$ yield as a light yellow power. ${ }^{1} \mathrm{H}$ NMR $\left(300 \mathrm{MHz}, \mathrm{CDCl}_{3}\right): \delta, \mathrm{ppm} 8.60(2 \mathrm{H}, \mathrm{s}), 7.37-7.43(10 \mathrm{H}, \mathrm{m}), 5.27(4 \mathrm{H}, \mathrm{s}), 2.61-2.69$ (4H, q), 2.18 (6H, s), 1.50-3.50 (br, $10 \mathrm{H}), 1.03-1.08$ (6H, t). ${ }^{13} \mathrm{C} \mathrm{NMR}\left(\mathrm{CDCl}_{3}, 75 \mathrm{MHz}\right)$ : $\delta$, ppm 161.8, 137.2, 133.1, 130.2, 129.9, 129.8, 129.5, 122.1, 121.6, 84.6, 67.9, 18.9, 16.5, 11.8. MALDI-TOF: [M] 624.76 .

\section{X-ray crystallographic data}

Crystals of $\mathbf{4 a}, \mathbf{4 c}, \mathbf{5 c}, \mathbf{5 c}-\mathbf{F}^{-}$complex and $\mathbf{7}$ for X-ray crystallographic analysis were grown by slow evaporation of their dichloromethane solutions. Diffraction data were collected at low temperature on a Nonius KappaCCD diffractometer equipped with MoK $\alpha$ radiation $(\lambda=$ $0.71073 \AA$ ) and an Oxford Cryosystems Cryostream chiller. Refinement was by full-matrix least squares using SHELXL, with $\mathrm{H}$ atoms in idealized positions, except for NH hydrogen atoms, which were located by difference maps and their positions refined. One of the ethyl groups in $\mathbf{4 c}$ was disordered into two orientations, as is one of the DCM molecules in the $\mathbf{5 c}$ fluoride complex. Crystallographic data: For $4 a: \mathrm{C}_{32} \mathrm{H}_{32} \mathrm{~N}_{2} \mathrm{O}_{4}$, monoclinic space group P2/c, $\mathrm{a}=9.870(2), \mathrm{b}=10.635(2), \mathrm{c}=13.545(2) \AA, \beta=105.469(10)^{\circ}, \mathrm{V}=1370.3(4) \AA^{3}, \mathrm{~T}=$ 90.0(5) K, $\mathrm{Z}=2, \rho_{\text {calcd }}=1.233 \mathrm{~g} \mathrm{~cm}^{-3}, \mu(\mathrm{MoK} \alpha)=0.081 \mathrm{~mm}^{-1}$. A total of 20,271 data was collected at to $\theta=28.8^{\circ}$. $\mathrm{R}=0.041$ for 2783 data with $\mathrm{Fo}^{2}>2 \sigma\left(\mathrm{Fo}^{2}\right)$ of 3549 unique data and 178 refined parameters, $\mathrm{CCDC} 821407$. For $\mathbf{4 c}$ : $\mathrm{C}_{20} \mathrm{H}_{24} \mathrm{~N}_{2} \mathrm{O}_{4}$, orthorhombic space group Pbca, $\mathrm{a}=13.889(2), \mathrm{b}=14.845(4), \mathrm{c}=18.920(5) \AA, \mathrm{V}=3901.0(16) \AA^{3}, \mathrm{~T}=120.0(5)$ $\mathrm{K}, \mathrm{Z}=8, \rho_{\text {calcd }}=1.214 \mathrm{~g} \mathrm{~cm}^{-3}, \mu(\mathrm{MoK} \alpha)=0.085 \mathrm{~mm}^{-1} .19,130$ total data, $\theta_{\max }=22.5^{\circ} . \mathrm{R}$ $=0.042$ for 1838 data with $\mathrm{Fo}^{2}>2 \sigma\left(\mathrm{Fo}^{2}\right)$ of 3549 unique data and 264 refined parameters, CCDC 779360. For 5c: $\mathrm{C}_{26} \mathrm{H}_{29} \mathrm{~N}_{3} \mathrm{O}_{4}$, triclinic space group P-1, $\mathrm{a}=10.244(2), \mathrm{b}=$ 10.789(2), $\mathrm{c}=12.516(3) \AA, \alpha=107.091(12), \beta=111.886(10), \gamma=97.204(13)^{\circ}, \mathrm{V}=$ 1183.1(5) $\AA^{3}, \mathrm{~T}=90.0(5) \mathrm{K}, \mathrm{Z}=2, \rho_{\text {calcd }}=1.256 \mathrm{~g} \mathrm{~cm}^{-3}, \mu(\mathrm{MoK} \alpha)=0.086 \mathrm{~mm}^{-1} .18,860$ total data, $\theta_{\max }=26.4^{\circ} . \mathrm{R}=0.048$ for 3352 data with $\mathrm{Fo}^{2}>2 \sigma\left(\mathrm{Fo}^{2}\right)$ of 4813 unique data and 312 refined parameters, CCDC 779361. For $\mathbf{5 c}-\mathbf{F}^{-}$complex: $\left(\mathrm{C}_{16} \mathrm{H}_{36} \mathrm{~N}\right)\left(\mathrm{C}_{26} \mathrm{H}_{29} \mathrm{~N}_{3} \mathrm{O}_{4}\right)_{2} \mathrm{~F}$. $1.5\left(\mathrm{CH}_{2} \mathrm{Cl}_{2}\right)$ triclinic space group $\mathrm{P}-1, \mathrm{a}=8.7265(10), \mathrm{b}=15.106(2), \mathrm{c}=27.490(3) \AA, \alpha=$ 74.955(6), $\beta=84.843(7), \gamma=78.574(7)^{\circ}, \mathrm{V}=3427.4(7) \AA^{3}, \mathrm{~T}=90.0(5) \mathrm{K}, \mathrm{Z}=2, \rho_{\text {calcd }}=$ $1.244 \mathrm{~g} \mathrm{~cm}^{-3}, \mu(\mathrm{MoK} \alpha)=0.195 \mathrm{~mm}^{-1} .51,056$ total data, $\theta_{\max }=27.1^{\circ} . \mathrm{R}=0.108$ for 8547 data with $\mathrm{Fo}^{2}>2 \sigma\left(\mathrm{Fo}^{2}\right)$ of 14,946 unique data and 819 refined parameters, CCDC 779362. For 7: $\mathrm{C}_{32} \mathrm{H}_{42} \mathrm{~B}_{10} \mathrm{~N}_{2} \mathrm{O}_{4}$, triclinic space group $\mathrm{P}-1, \mathrm{a}=11.651(2), \mathrm{b}=11.903(2), \mathrm{c}=$ 12.1444(17) $\AA, \alpha=96.959(10), \beta=91.123(9), \gamma=92.222(7)^{\circ}, \mathrm{V}=1670.0(5) \AA^{3}, \mathrm{~T}=$ 115.0(5) $\mathrm{K}, \mathrm{Z}=2, \rho_{\text {calcd }}=1.246 \mathrm{~g} \mathrm{~cm}^{-3}, \mu(\mathrm{MoK} \alpha)=0.075 \mathrm{~mm}^{-1} .35,739$ total data, $\theta_{\max }=$ $26.0^{\circ} . \mathrm{R}=0.044$ for 4850 data with $\mathrm{Fo}^{2}>2 \sigma\left(\mathrm{Fo}^{2}\right)$ of 6566 unique data and 444 refined parameters, CCDC 821406.

Crystallographic data have been deposited at the Cambridge Crystallographic Data Center (CCDC) under above-cited deposition numbers. Copies can be obtained on request, free of charge, via www.ccdc.cam.ac.uk/conts/retrieving.html or from the Cambridge Crystallographic Data Center, 12 Union Road, Cambridge CB2 1EZ, UK (fax: +44 1223-336-033 or email: deposit@ccdc.cam.ac.uk).

\section{CONCLUSION}

We have developed an efficient one-pot double Sonagashira coupling reaction from which a series of dipyrrolylethynes (4a-d) has been synthesized using an improved route from trimethylsilylethyne and various 2-halopyrroles. The resulting dipyrrolylethynes were further transformed into various novel dipyrroles (5-7) using the Larock indole synthesis, 
stereoselective catalytic hydrogenation, or reaction with $\mathrm{B}_{10} \mathrm{H}_{14}$. These novel dipyrroles should be valuable building blocks for the construction of elaborate pyrrole-containing functional molecules and materials. In addition, indolyl-dipyrroles $\mathbf{5}$ were found to selectively bind fluoride ions with high affinity, forming a 2:1 complex involving one pyrrolic $\mathrm{NH}$ and the indole $\mathrm{NH}$.

\section{Acknowledgments}

The work described was supported by grants from the US National Institutes of Health, (CA 132861; KMS) and the US National Science Foundation (CHE 0911629; MGHV). The purchase of the X-ray diffractometer was made possible by Grant No. LEQSF(1999-2000)-ENH-TR-13, administered by the Louisiana Board of Regents.

\section{References}

1. a) Kadish, KM.; Smith, KM.; Guilard, R., editors. The Porphyrin Handbook. Vol. 6. Academic Press; San Diego: 2000. b) Dismukes GC. Science. 2001; 292:447. [PubMed: 11330297] c) Chang CJ, Chng LL, Nocera DG. J Am Chem Soc. 2003; 125:1866. [PubMed: 12580614]

2. a) Sessler JL, An D, Cho W-S, Lynch V. Angew Chem Int Ed. 2003; 42:2278.b) Sessler JL, An D, Cho WS, Lynch V. J Am Chem Soc. 2003; 125:13646. [PubMed: 14599187] c) Geier GR III, Grindrod SC. J Org Chem. 2004; 69:6404. [PubMed: 15357601] d) Jolicoeur B, Lubell WD. Org Lett. 2006; 8:6107. [PubMed: 17165941] e) Roznyatovskiy VV, Roznyatovskaya NV, Weyrauch H, Pinkwart K, Tubke J, Sessler JL. J Org Chem. 2010; 75:8355. [PubMed: 21090640] f) Jiao L, Yu C, Liu M, Cong K, Meng T, Wang Y, Hao E. J Org Chem. 2010; 75:6035. [PubMed: 20690775] g) Sessler, JL.; Weghorn, SJ. Expanded, Contracted and Isomeric Porphyrins. Pergamon Press; New York: 1997.

3. Jux N, Koch P, Schmickler H, Lex J, Vogel E. Angew Chem Int Ed. 1990; 29:1385.

4. Cho DH, Lee JH, Kim BH. J Org Chem. 1999; 64:8048.

5. Tu B, Ghosh B, Lightner DA. J Org Chem. 2003; 68:8950. [PubMed: 14604367]

6. Mio MJ, Kopel LC, Braun JB, Gadzikwa TL, Hull KL, Brisbois RG, Markworth CJ, Grieco PA. Org Lett. 2002; 4:3199. [PubMed: 12227748]

7. a) Black CB, Andrioletti B, Try AC, Ruiperez C, Sessler JL. J Am Chem Soc. 1999; 121:10438.b) Anzenbacher P Jr, Try AC, Miyaji H, Jursíková K, Lynch VM, Marquez M, Sessler JL. J Am Chem Soc. 2000; 122:10268.c) Mizuno T, Wei W-H, Eller LR, Sessler JL. J Am Chem Soc. 2002; 124:1134. [PubMed: 11841258] d) Sessler JL, Maeda H, Mizuno T, Lynch VM, Furuta H. J Am Chem Soc. 2002; 124:13474. [PubMed: 12418900] e) Yoo J, Kim M-S, Hong S-J, Sessler JL, Lee C-H. J Org Chem. 2009; 74:1065. [PubMed: 19093780]

8. Ghosh T, Maiya BG, Wong MW. J Phys Chem A. 2004; 108:11249.

9. Amendola V, Esteban-Gómez D, Fabbrizzi L, Licchelli M. Acc Chem Res. 2006; 39:343. [PubMed: 16700533]

10. a) Clark JC, Fabre B, Fronczek FR, Vicente MGH. J Porphyrins Phthalocyanines. 2005; 9:803.b) Fabre B, Clark JC, Vicente MGH. Macromolecules. 2006; 39:112.c) Hao E, Fabre B, Fronczek FR, Vicente MGH. Chem Commun. 2007:4387.d) Hao E, Fabre B, Fronczek FR, Vicente MGH. Chem Mater. 2007; 19:6195.

11. a) Lee DA, Xie H, Senge MO, Smith KM. J Chem Soc, Chem Commun. 1994:791.b) Xie H, Lee DA, Wallace DM, Senge MO, Smith KM. J Org Chem. 1996; 61:8508.

12. a) Jiao LJ, Hao EH, Fronczek FR, Vicente MGH, Smith KM. J Porphyrins Phthalocyanines. 2011; 15:433.b) Jiao L, Hao E, Vicente MGH, Smith KM. J Org Chem. 2007; 72:8119. [PubMed: 17887702]

13. Chinchilla R, Najera C. Chem Rev. 2007; 107:874. [PubMed: 17305399]

14. a) Tanui H, Fronczek FR, Vicente MGH. Acta Crystallogr. 2007; E64:o75.b) Tanui H, Fronczek FR, Vicente MGH. Acta Crystallogr. 2007; E64:o130.

15. Larock RC, Yum EK. J Am Chem Soc. 1991; 113:6689.

16. a) Lindlar H, Dubuis R. Org Synth. 1973; 5:880.b) Takeda H, Watanabe H, Nakada M. Tetrahedron. 2006; 62:8054. 
17. Luo F, Pan C, Wang W, Ye Z, Cheng J. Tetrahedron. 2010; 66:1399.

18. Jiang W, Knobler CB, Hawthorne MF. Inorg Chem. 1996; 35:3056.

19. Fery-Forgues S, Lavabre D. J Chem Educ. 1999; 76:1260. 


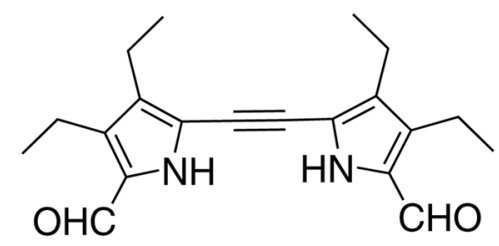

(a)

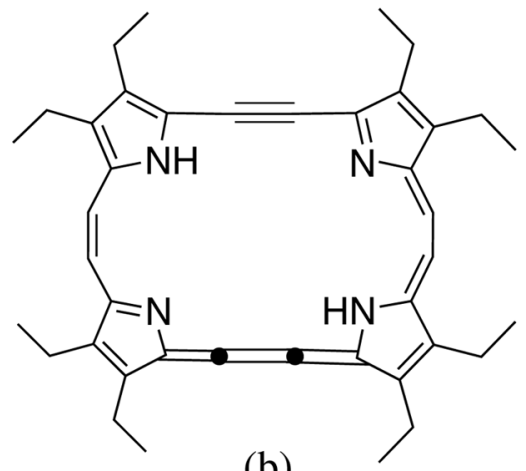

(b)

Fig. 1.

Structures of dipyrrolylethyne (a) and expanded porphycene precursor (b) synthesized by Vogel and coworkers [3] 


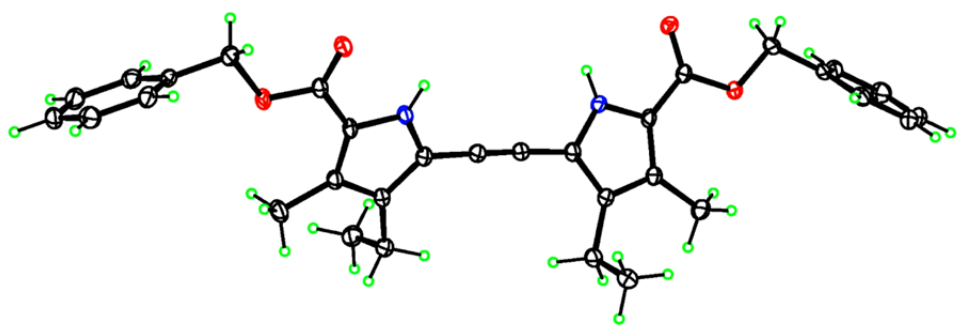

Fig. 2.

Molecular structure of dipyrrolylethyne $\mathbf{4 a}$, with $50 \%$ ellipsoids 


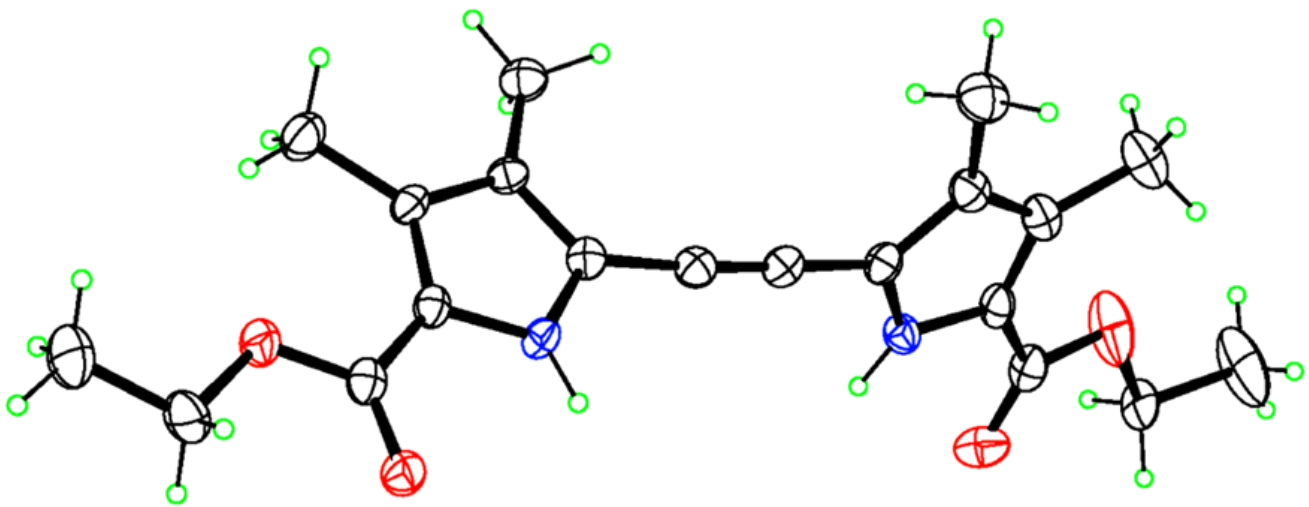

Fig. 3.

Molecular structure of dipyrrolylethyne $\mathbf{4 c}$, with $50 \%$ ellipsoids 


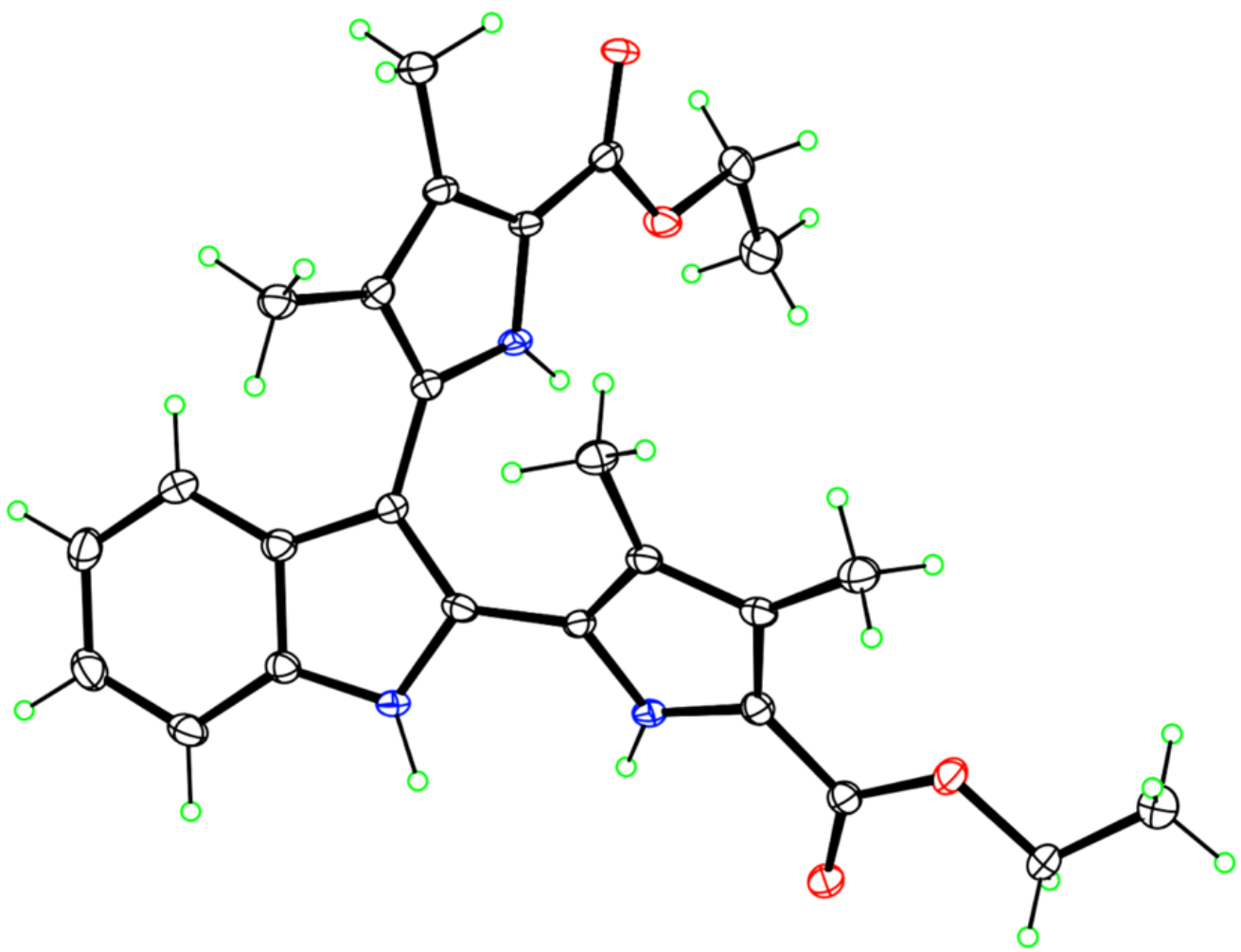

Fig. 4.

Molecular structure of bipyrrole 5c, with 50\% ellipsoids 


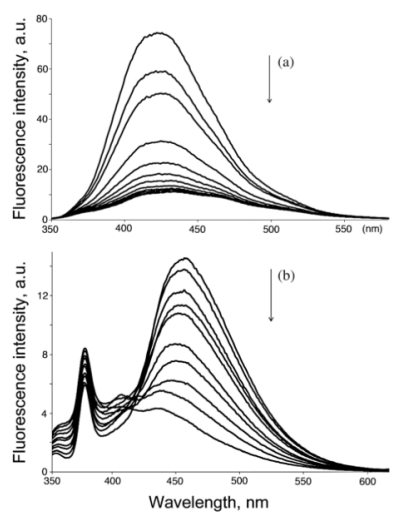

Fig. 5.

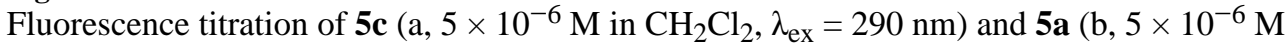
in $\left.\mathrm{CH}_{2} \mathrm{Cl}_{2}, \lambda_{\mathrm{ex}}=290 \mathrm{~nm}\right)$ with $\operatorname{TBAF}(0-100 \mathrm{eq})$ 


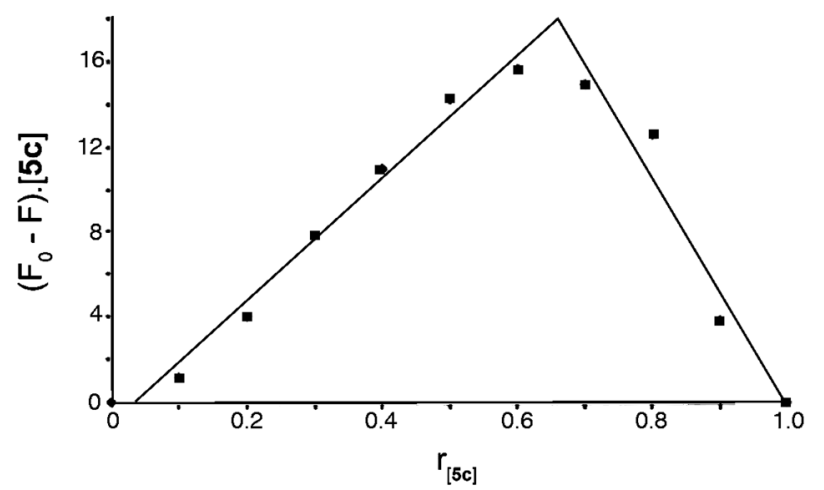

(a)

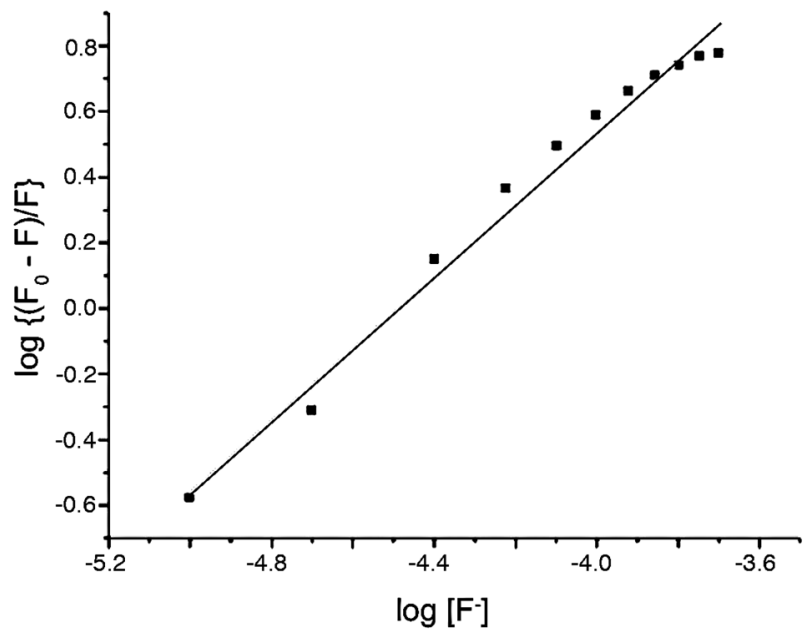

(b)

Fig. 6.

Job's plot (a) and Hill plot (b) of 5c: $\mathrm{F}^{-}$complex with a 2:1 stoichiometry, $\left(\mathrm{F}_{0}-\mathrm{F}\right)=$ change in fluorescence, $[\mathbf{5 c}]$ and $\mathbf{r}_{[\mathbf{5 c}]}=$ moles and mole fraction for $\mathbf{5 c}$, excitation at $290 \mathrm{~nm}$ 


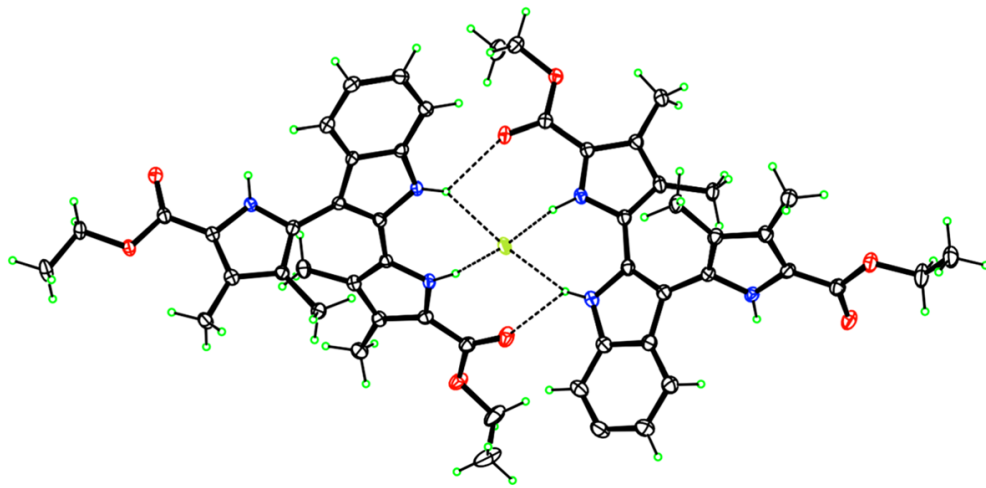

Fig. 7.

Molecular structure of the 2:1 molar-ratio 5c-fluoride complex 

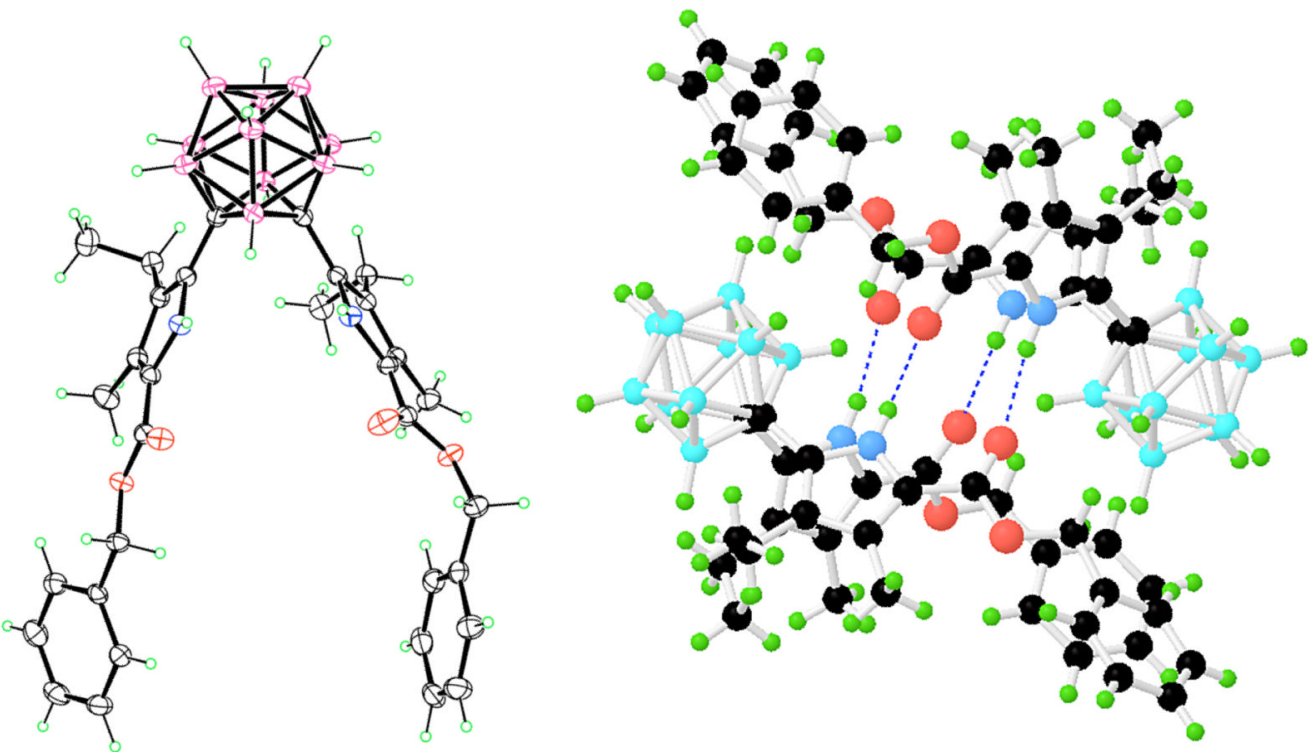

Fig. 8.

Molecular structure of bipyrrole 7 (50\% ellipsoids, left) and its hydrogen bonded dimer (right) 


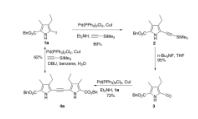

Scheme 1.

Synthesis of dipyrrolylethyne 4a using two different routes 
<smiles>[R]OC(=O)c1[nH]c(C#Cc2[nH]c(C(=O)O[Tl])c(C)c2[R])c([R])c1C</smiles>

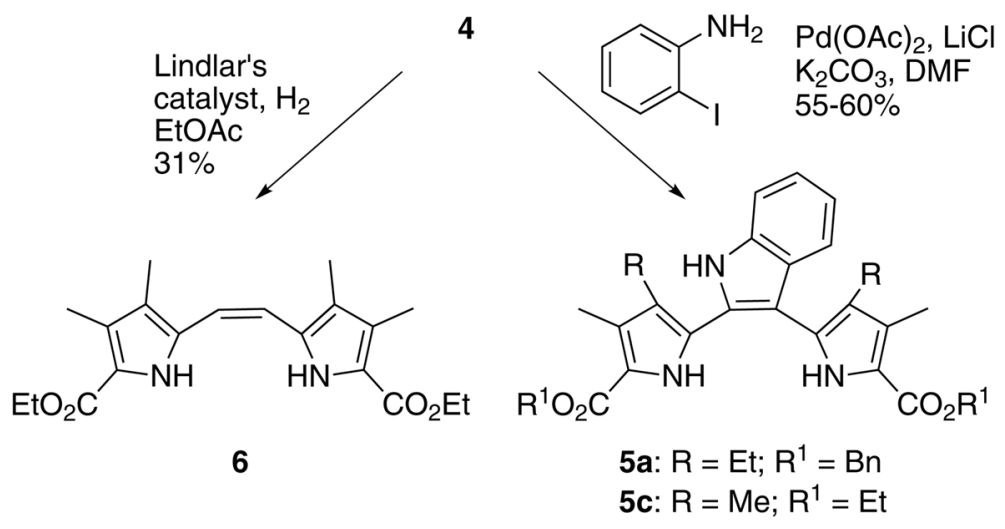

Scheme 2.

Synthesis of dipyrroles 5 and $\mathbf{6}$ 


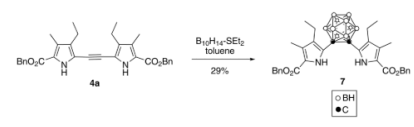

Scheme 3.

Synthesis of carboranyldipyrrole 7 


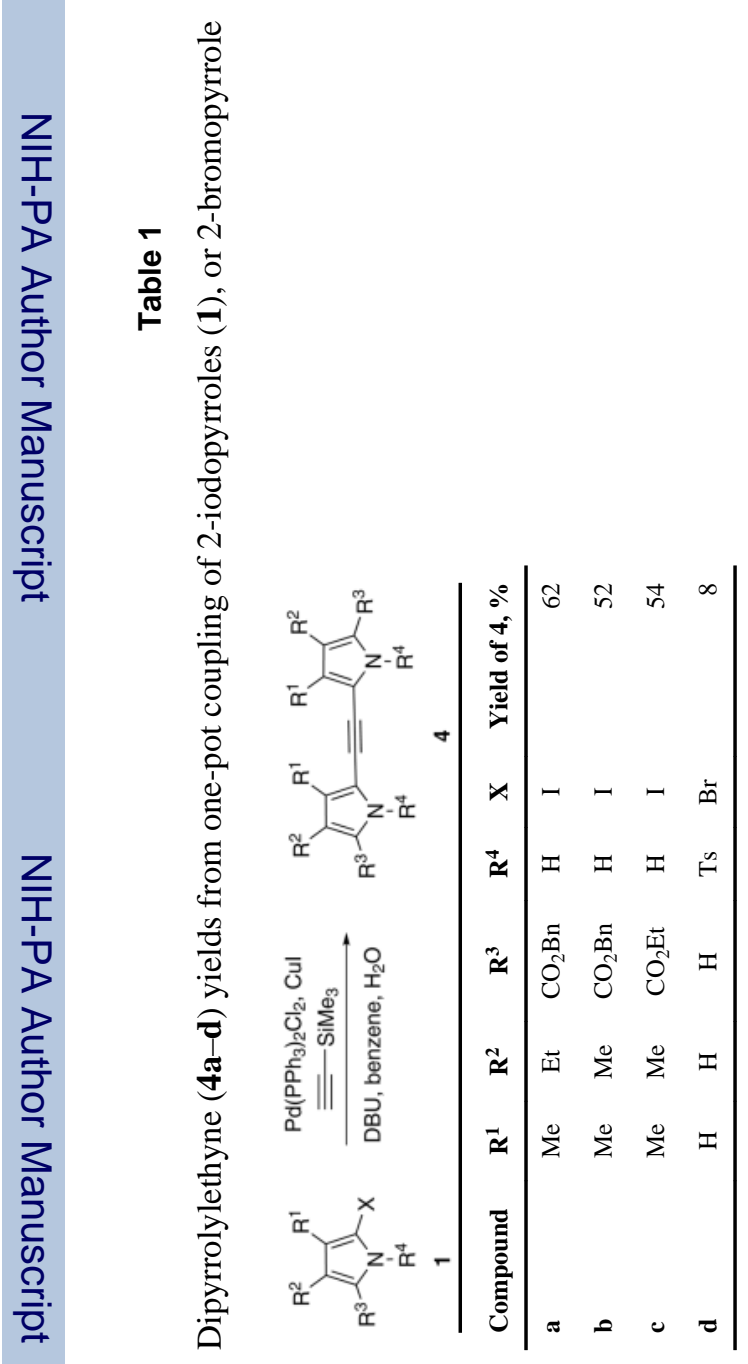


Table 2

Photophysical properties of dipyrroles $\mathbf{4}$ and $\mathbf{5}$ in $\mathrm{CH}_{2} \mathrm{Cl}_{2}$ at room temperature

\begin{tabular}{lcccr}
\hline Compound & $\lambda_{\text {max }}, \mathbf{n m}$ & $\boldsymbol{\lambda}_{\mathrm{em}}{ }^{\boldsymbol{a}}, \mathbf{n m}$ & $\boldsymbol{\Phi}^{\boldsymbol{b}}$ & Stokes' shift, $\mathbf{n m}$ \\
\hline $\mathbf{4 c}$ & 339 & 414 & 0.01 & 75 \\
$\mathbf{4 a}$ & 343 & 400 & 0.01 & 57 \\
$\mathbf{5 c}$ & 292 & 439 & 0.88 & 147 \\
$\mathbf{5 a}$ & 295 & 440 & 0.91 & 145 \\
\hline
\end{tabular}

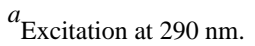

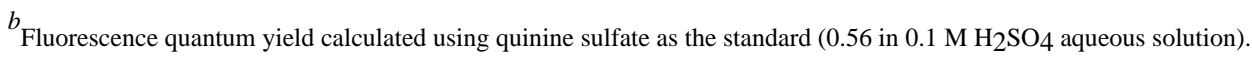

